Article

\title{
Struvite Precipitation for Ammonia Nitrogen Removal in 7-Aminocephalosporanic Acid Wastewater
}

\author{
Zaixing Li ${ }^{1,2}$, Xuguang Ren ${ }^{1}$, Jiane Zuo ${ }^{2}$, Yanfang Liu ${ }^{1}$, Erhong Duan ${ }^{1, *}$, Jingliang Yang ${ }^{1{ }^{1} *}$, \\ Ping Chen ${ }^{3}$ and Yongjun Wang ${ }^{3}$
}

1 School of Environmental Science and Engineering, Hebei University of Science and Technology, Shijiazhuang 050018, China; E-Mails: Li_zaixing@163.com (Z.L.); 275716074@qq.com (X.R.); liuyanfang1984@163.com (Y.L.)

2 Department of Environmental Science and Engineering, Tsinghua University, Beijing 100084, China; E-Mail: jiane.zuo@tsinghua.edu.cn

3 North China Pharmaceutical Company, Shijiazhuang 050015, China; E-Mails: chenping@ncpc.com (P.C.); wyjkx@163.com (Y.W.)

* Authors to whom correspondence should be addressed; E-Mails: deh@hebust.edu.cn (E.D.); yangjingliang@sina.com (J.Y.); Tel.: +86-311-8863-2210; Fax: +86-311-8863-2210.

Received: 4 January 2012; in revised form: 14 February 2012 / Accepted: 15 February 2012 / Published: 21 February 2012

\begin{abstract}
Aminocephalosporanic acid wastewater usually contains high concentrations of ammonium $\left(\mathrm{NH}_{4}{ }^{+}-\mathrm{N}\right)$, which is known to inhibit nitrification during biological treatment processes. Chemical precipitation is a useful technology to remove ammonium from wastewater. In this paper, the removal of ammonium from 7-aminocephalosporanic acid wastewater was studied. The optimum $\mathrm{pH}$, molar ratio, and various chemical compositions of magnesium ammonium phosphate (MAP) precipitation were investigated. The results indicated that ammonium in 7-aminocephalosporanic acid wastewater could be removed at an optimum $\mathrm{pH}$ of 9 . The $\mathrm{Mg}^{2+}: \mathrm{NH}_{4}{ }^{+}-\mathrm{N}: \mathrm{PO}_{4}{ }^{3-}-\mathrm{P}$ molar ratio was readily controlled at a ratio of $1: 1: 1.1$ to both effectively remove ammonium and avoid creating a higher concentration of $\mathrm{PO}_{4}{ }^{3-}-\mathrm{P}$ in the effluent. $\mathrm{MgCl}_{2} \cdot 6 \mathrm{H}_{2} \mathrm{O}+85 \% \mathrm{H}_{3} \mathrm{PO}_{4}$ was the most efficient combination for $\mathrm{NH}_{4}{ }^{+}-\mathrm{N}$ removal. Furthermore, the lowest concentration of the residual $\mathrm{PO}_{4}{ }^{3-}-\mathrm{P}$ was obtained with the same combination. Struvite precipitation could be considered an effective technology for the $\mathrm{NH}_{4}{ }^{+}-\mathrm{N}$ removal from the 7-aminocephalosporanic acid wastewater.
\end{abstract}


Keywords: struvite; 7-aminocephalosporanic acid; wastewater; ammonia nitrogen; precipitation

\section{Introduction}

7-Aminocephalosporanic acid (7-ACA) is one of the key intermediates in the production of medically important semisynthetic cephalosporins, such as cephalaglycin and cephalothin. Currently, an enzyme-mediated process for the synthesis of 7-ACA from cephalosporin $\mathrm{C}$ has been recommended as an environmentally friendly technology compared to the conventional chemical synthetic process. During the enzyme-mediated process for the synthesis of 7-ACA, high levels of ammonium nitrogen $\left(\mathrm{NH}_{4}{ }^{+} \mathrm{N}\right)$ and high chemical oxygen demand (COD) were found in the wastewater. $\mathrm{NH}_{4}{ }^{+}-\mathrm{N}$ present in wastewater at excess levels may deteriorate the receiving water quality [1]. In addition, $\mathrm{NH}_{4}{ }^{+} \mathrm{N}$ is harmful to the local ecology [2]. Therefore, these compounds should be removed from the wastewater before entering into aquatic systems. However, the 7-ACA wastewater it is hard to bioremediate, because of the high concentrations of $\mathrm{NH}_{4}{ }^{+}-\mathrm{N}$, a small quantity of cephalosporin and 7-ACA that can inhibit the growth of, and even destroy, harmful microorganisms. To overcome this difficulty, the precipitation of $\mathrm{NH}_{4}{ }^{+}-\mathrm{N}$ by forming magnesium ammonium phosphate (struvite, $\mathrm{MgNH}_{4} \mathrm{PO}_{4} \cdot 6 \mathrm{H}_{2} \mathrm{O}$ ) is an attractive means of 7-ACA wastewater treatment. $\mathrm{NH}_{4}{ }^{+}-\mathrm{N}$ recovered by sturvite may be reused as slow release fertilizer. Struvite crystallizes is a white orthorhombic crystalline structure consisting of magnesium, ammonium, and phosphate in equal molar concentrations [3]. The basic chemical reaction to form struvite is expressed in Equation (1) [4]:

$$
\mathrm{Mg}^{2+}+\mathrm{NH}_{4}^{+}+\mathrm{H}_{\mathrm{n}} \mathrm{PO}_{4}{ }^{3-\mathrm{n}}+6 \mathrm{H}_{2} \mathrm{O} \leftrightarrow \mathrm{MgNH}_{4} \mathrm{PO}_{4} \cdot 6 \mathrm{H}_{2} \mathrm{O}+\mathrm{nH}^{+}(\mathrm{n}=0,1,2)
$$

The method of chemical precipitation of $\mathrm{NH}_{4}{ }^{+}-\mathrm{N}$ in the form of struvite has been studied widely from various types of wastewaters such as landfill leachate [5], industrial wastewater [6], source-separated human urine [7], anaerobic swine lagoon liquid [8] and semiconductor wastewater [9]. Münch and Barr [10] have reported that the success of struvite precipitation depended on two main factors: $\mathrm{Mg}^{2+}: \mathrm{NH}_{4}{ }^{+}-\mathrm{N}: \mathrm{PO}_{4}{ }^{3-}-\mathrm{P}$ ratio and the $\mathrm{pH}$ of the solution. $\mathrm{Li}$ and $\mathrm{Zhao}$ [11] found that under an equal molar ratio of $\mathrm{Mg}^{2+}: \mathrm{NH}_{4}{ }^{+}-\mathrm{N}: \mathrm{PO}_{4}{ }^{3-}-\mathrm{P}$, the $\mathrm{NH}_{4}{ }^{+}-\mathrm{N}$ concentration could quickly be reduced from $5,618 \mathrm{mg} / \mathrm{L}$ to $112 \mathrm{mg} / \mathrm{L}$ by pretreating the chemical precipitation. Uludag-Demirer [12] and co-workers treated dairy manure by struvite precipitation and demonstrated that over $92 \%$ of $\mathrm{NH}_{4}{ }^{+}-\mathrm{N}$ removal was possible by adding $\mathrm{Mg}^{2+}$ ions at a concentration higher than $0.06 \mathrm{M}$. Ryu [13] studied the struvite precipitation process in semiconductor wastewater at the field-scale and found that the optimum reaction for ammonium nitrogen removal occurred at a $\mathrm{pH}$ of 9.2. Marti [14] has reported that the struvite solubility decreases when the $\mathrm{pH}$ increases.

Struvite precipitation has been considered an effective technology for $\mathrm{NH}_{4}{ }^{+} \mathrm{N}$ removal. Previous studies have tested chemical precipitations and obtained several empirical parameters. The chemicals used as $\mathrm{Mg}^{2+}$ and $\mathrm{PO}_{4}{ }^{3-}-\mathrm{P}$ ions source along with the molar ratios of $\mathrm{Mg}^{2+}: \mathrm{NH}_{4}{ }^{+}: \mathrm{PO}_{4}{ }^{3-}$ adopted, the optimal $\mathrm{pH}$ values determined and the removal efficiencies achieved by struvite precipitation are summarized in Table 1. However, many reaction factors, such as $\mathrm{pH}$, the molar ratio of $\mathrm{Mg}^{2+}: \mathrm{NH}_{4}{ }^{+}-\mathrm{N}: \mathrm{PO}_{4}{ }^{3-}-\mathrm{P}$, initial $\mathrm{NH}_{4}{ }^{+}-\mathrm{N}$ concentration and interfering ions that influence struvite 
precipitation, are less well studied, hampering the wide application of chemical precipitation. To the best of our knowledge, the feasibility of struvite precipitation in 7-ACA wastewater has not yet been studied.

Table 1. Removal of $\mathrm{NH}_{4}{ }^{+}-\mathrm{N}$ and $\mathrm{PO}_{4}{ }^{3-}$-P by struvite precipitation from different wastewaters.

\begin{tabular}{|c|c|c|c|c|c|c|c|c|}
\hline \multirow[t]{2}{*}{ Type of the waste } & \multirow[t]{2}{*}{ Chemicals added } & \multirow{2}{*}{$\begin{array}{c}\text { Amount of the } \\
\text { chemicals } \\
\mathrm{Mg}^{2+}: \mathrm{NH}_{4}{ }^{+}-\mathrm{N}: \\
\mathrm{PO}_{4}{ }^{3-}-\mathrm{P}\end{array}$} & \multicolumn{2}{|c|}{$\begin{array}{c}\text { Initial } \\
\text { concentrations } \\
(\mathbf{m g} / \mathbf{L}) \\
\end{array}$} & \multicolumn{2}{|c|}{ Removal (\%) } & \multirow[t]{2}{*}{$\mathbf{p H}$} & \multirow[t]{2}{*}{ Ref. } \\
\hline & & & $\mathrm{NH}_{4}{ }^{+}-\mathrm{N}$ & COD & $\mathrm{NH}_{4}{ }^{+}-\mathrm{N}$ & COD & & \\
\hline Landfill leachates & $\begin{array}{c}\mathrm{MgCl}_{2} \cdot 6 \mathrm{H}_{2} \mathrm{O}+ \\
\mathrm{Na}_{2} \mathrm{HPO}_{4} \cdot 12 \mathrm{H}_{2} \mathrm{O}\end{array}$ & $1: 1: 1$ & 2750 & 3720 & 92 & NI & 9 & [5] \\
\hline $\begin{array}{c}\text { Industrial } \\
\text { wastewater }\end{array}$ & Bittern $+\mathrm{KH}_{2} \mathrm{PO}_{4}$ & 1.6:0.6:1 & 110 & NI & 91 & NI & 9.6 & [6] \\
\hline $\begin{array}{c}\text { Effluent of a } \\
\text { sewage sludge } \\
\text { anaerobic digester }\end{array}$ & $\begin{array}{c}\mathrm{MgCl}_{2} \cdot 6 \mathrm{H}_{2} \mathrm{O}+ \\
85 \% \mathrm{H}_{3} \mathrm{PO}_{4}\end{array}$ & $1.5: 1: 1$ & 749 & 936.4 & 89.35 & 39.78 & 9 & {$[10]$} \\
\hline Coking wastewater & $\begin{array}{c}\mathrm{MgCl}_{2} \cdot 6 \mathrm{H}_{2} \mathrm{O}+ \\
\mathrm{Na}_{2} \mathrm{HPO}_{4} \cdot 12 \mathrm{H}_{2} \mathrm{O}\end{array}$ & $1: 1: 1$ & 500 & 200 & 88 & NI & 9.5 & {$[15]$} \\
\hline $\begin{array}{l}\text { Effluent of UASB } \\
\text { treating poultry } \\
\text { manure wastewater }\end{array}$ & $\begin{array}{c}\mathrm{MgCl}_{2} \cdot 6 \mathrm{H}_{2} \mathrm{O}+ \\
\mathrm{KH}_{2} \mathrm{PO}_{4}\end{array}$ & $1: 1: 1$ & 1318 & 1800 & 85.4 & 54 & 9 & {$[16]$} \\
\hline $\begin{array}{l}\text { Effluent from the } \\
\text { anaerobic } \\
\text { treatment of the } \\
\text { baker's yeast } \\
\text { industry }\end{array}$ & $\begin{array}{c}\mathrm{MgCl}_{2} \cdot 6 \mathrm{H}_{2} \mathrm{O}+ \\
\mathrm{Na}_{2} \mathrm{HPO}_{4}\end{array}$ & $1.1: 1: 1.1$ & 735 & NI & 83 & NI & 9.2 & {$[17]$} \\
\hline Swine wastewater & $\begin{array}{c}\mathrm{MgCl}_{2} \cdot 6 \mathrm{H}_{2} \mathrm{O}+ \\
\mathrm{K}_{2} \mathrm{HPO}_{4} \\
\end{array}$ & $1: 1: 1$ & 844.5 & 2139 & 88 & 47 & 9 & {$[18]$} \\
\hline
\end{tabular}

The objective of this study is to investigate the removal of $\mathrm{NH}_{4}{ }^{+}-\mathrm{N}$ by struvite precipitation from 7-ACA wastewater using different magnesium and phosphate sources. In the experiments, the evaluations were focused on the following objectives: (1) optimizing the effects of operating parameters, such as the $\mathrm{pH}, \mathrm{Mg}^{2+}: \mathrm{NH}_{4}{ }^{+}-\mathrm{N}: \mathrm{PO}_{4}{ }^{3-}-\mathrm{P}$ molar ratio and mixing time for the precipitate; (2) appraising the performance of struvite precipitation on residual $\mathrm{PO}_{4}{ }^{3-}-\mathrm{P}$ and COD removal; and (3) examining the physical properties of the struvite products.

\section{Results and Discussion}

\subsection{Batch Testing with Nine Combinations of Chemicals}

In the first step of the struvite precipitation tests, nine combinations of chemicals denoted A1-A9 were tested with an initial $\mathrm{NH}_{4}{ }^{+}-\mathrm{N}$ concentration of $1,128 \mathrm{mg} / \mathrm{L}$. Based on the stoichiometry of the struvite precipitation $\left(\mathrm{Mg}^{2+}: \mathrm{NH}_{4}{ }^{+}-\mathrm{N}: \mathrm{PO}_{4}{ }^{3-}-\mathrm{P}=1: 1: 1\right)$, the required quantities of chemicals were calculated and added to the 7-ACA wastewater. The overall performance of the precipitation reaction in terms of $\mathrm{NH}_{4}{ }^{+}-\mathrm{N}$ removal, $\mathrm{COD}$ removal, residual $\mathrm{PO}_{4}{ }^{3-}-\mathrm{P}$ in solution, and the change of $\mathrm{pH}$ is shown in Figure 1. When $\mathrm{Mg}^{2+}$ was added as $\mathrm{MgO}$ (experiments $\mathrm{A} 1, \mathrm{~A} 2$ and $\mathrm{A} 3$ ) $\mathrm{NH}_{4}{ }^{+}-\mathrm{N}$ removal 
efficiencies were less than $40 \%$. This phenomenon can be attributed to the fact that $\mathrm{MgO}$ has limited solubility in water. In addition, a high level of $\mathrm{PO}_{4}{ }^{3-}$-P was unexpectedly observed after the reaction, which is problematic because residual $\mathrm{PO}_{4}{ }^{3-}-\mathrm{P}$ will cause additional pollution in aquatic ecosystems. However, for $\mathrm{MgCl}_{2} \cdot 6 \mathrm{H}_{2} \mathrm{O}$ and $\mathrm{MgSO}_{4}$ as alternate sources of $\mathrm{Mg}^{2+}, \mathrm{NH}_{4}{ }^{+}-\mathrm{N}$ removal efficiency increased up to $65 \%$. Furthermore, the residual concentration of $\mathrm{PO}_{4}{ }^{3-}-\mathrm{P}$ was relatively low compared to that of the previous experiments.

Figure1. $\mathrm{NH}_{4}{ }^{+}-\mathrm{N}$ removal, residual $\mathrm{PO}_{4}{ }^{3-}-\mathrm{P}, \mathrm{pH}$ and $\mathrm{COD}$ removal at a $\mathrm{pH}$ of 9 , $\mathrm{Mg}^{2+}: \mathrm{NH}_{4}{ }^{+}-\mathrm{N}: \mathrm{PO}_{4}{ }^{3-}-\mathrm{P}$ molar ratio of $1: 1: 1$ and a mixing time $15 \mathrm{~min}$.

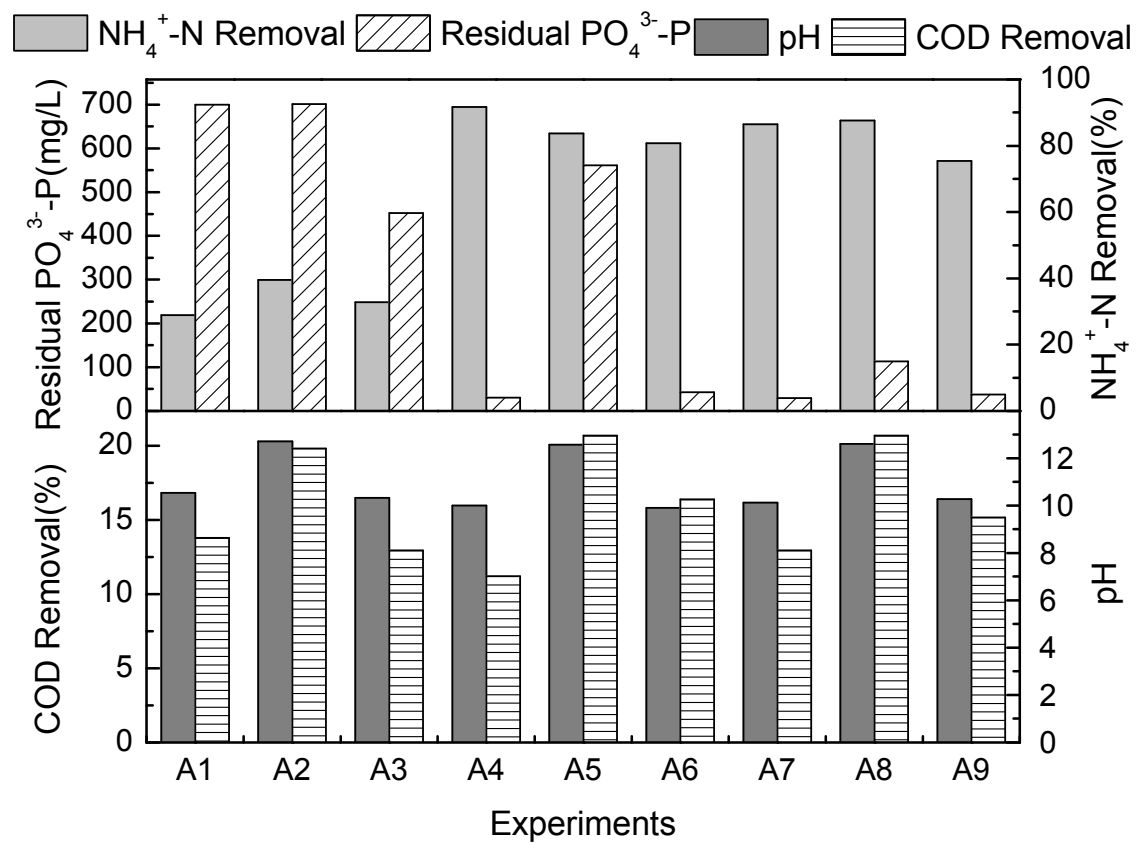

The addition of $\mathrm{Na}_{3} \mathrm{PO}_{4} \cdot 12 \mathrm{H}_{2} \mathrm{O}+\mathrm{MgSO}_{4}(\mathrm{~A} 8), \mathrm{NaH}_{2} \mathrm{PO}_{4} \cdot 12 \mathrm{H}_{2} \mathrm{O}+\mathrm{MgCl}_{2} \cdot 6 \mathrm{H}_{2} \mathrm{O}$ (A5), $85 \% \mathrm{H}_{3} \mathrm{PO}_{4}+$ $\mathrm{MgCl}_{2} \cdot 6 \mathrm{H}_{2} \mathrm{O}$ (A4) or $85 \% \mathrm{H}_{3} \mathrm{PO}_{4}+\mathrm{MgSO}_{4}$ (A7) each achieved highly efficient removal of $\mathrm{NH}_{4}{ }^{+}-\mathrm{N}$, with $70.92 \%, 67.83 \%, 74.28 \%$ and $70.02 \%$ of the total removed, respectively. To assess the quality of the struvite created through precipitation, the four combinations were analyzed by XRD and SEM analysis (Figure 2 and Figure 3). The XRD pattern generated from these samples matched the database model for struvite. The combination of $85 \% \mathrm{H}_{3} \mathrm{PO}_{4}+\mathrm{MgCl}_{2} \cdot 6 \mathrm{H}_{2} \mathrm{O}$ showed the strongest match, indicating that a relatively pure precipitate of struvite could be created using $85 \% \mathrm{H}_{3} \mathrm{PO}_{4}+\mathrm{MgCl}_{2} \cdot 6 \mathrm{H}_{2} \mathrm{O}$. The results obtained from SEM morphological analysis were compared with the XRD analysis. As shown in Figure 3, the needle-shaped spherical crystal precipitate of $85 \% \mathrm{H}_{3} \mathrm{PO}_{4}+\mathrm{MgCl}_{2} \cdot 6 \mathrm{H}_{2} \mathrm{O}$ was more distinct than the others, and its size was regular (radius $25-28 \mathrm{~nm}$ ). Therefore, $85 \% \mathrm{H}_{3} \mathrm{PO}_{4}+$ $\mathrm{MgCl}_{2} \cdot 6 \mathrm{H}_{2} \mathrm{O}$ is proposed as the best condition to achieve maximum removal of $\mathrm{NH}_{4}{ }^{+}-\mathrm{N}$ from the 7-ACA wastewater. 
Figure 2. $\mathrm{XRD}$ diffractograms of precipitates for four chosen chemical combinations at $\mathrm{pH}$ 9 and a $\mathrm{Mg}^{2+}: \mathrm{NH}_{4}{ }^{+}-\mathrm{N}: \mathrm{PO}_{4}{ }^{3-}-\mathrm{P}$ molar ratio of $1: 1: 1$, (a) $\mathrm{Na}_{3} \mathrm{PO}_{4} \cdot 12 \mathrm{H}_{2} \mathrm{O}+\mathrm{MgSO}_{4}$; (b) $\mathrm{NaH}_{2} \mathrm{PO}_{4} \cdot 12 \mathrm{H}_{2} \mathrm{O}+\mathrm{MgCl}_{2} \cdot 6 \mathrm{H}_{2} \mathrm{O}$; (c) $85 \% \mathrm{H}_{3} \mathrm{PO}_{4}+\mathrm{MgSO}_{4} ;$ (d) $85 \% \mathrm{H}_{3} \mathrm{PO}_{4}+$ $\mathrm{MgCl}_{2} \cdot 6 \mathrm{H}_{2} \mathrm{O}$.

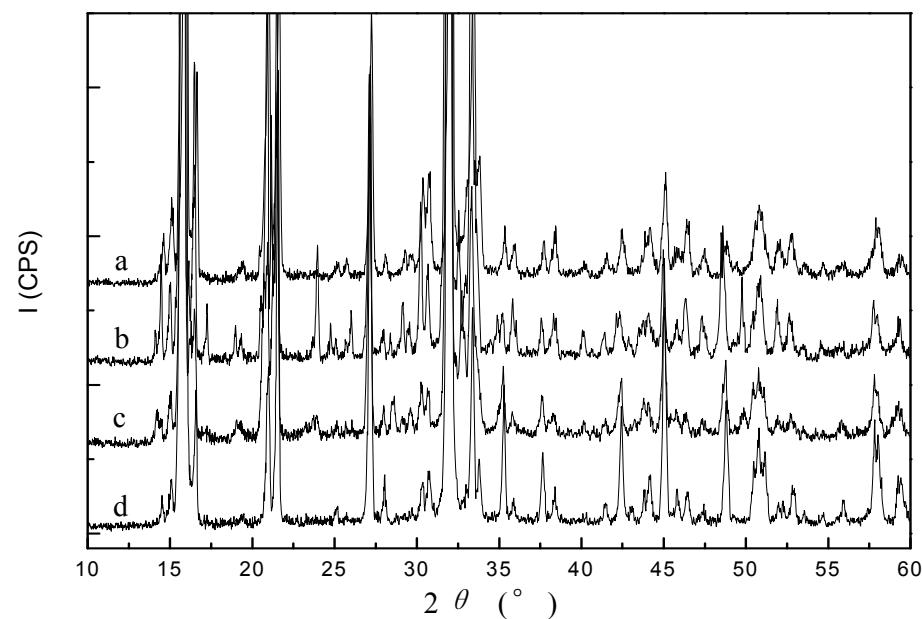

Figure 3. Morphology of struvite precipitations for four chosen chemical combinations at pH 9 and a $\mathrm{Mg}^{2+}: \mathrm{NH}_{4}{ }^{+}-\mathrm{N}: \mathrm{PO}_{4}{ }^{3-}-\mathrm{P}$ molar ratio of $1: 1: 1$ as analyzed via SEM: (a) $\mathrm{Na}_{3} \mathrm{PO}_{4} \cdot 12 \mathrm{H}_{2} \mathrm{O}+\mathrm{MgSO}_{4}$; (b) $\mathrm{NaH}_{2} \mathrm{PO}_{4} \cdot 12 \mathrm{H}_{2} \mathrm{O}+\mathrm{MgCl}_{2} \cdot 6 \mathrm{H}_{2} \mathrm{O}$; (c) $85 \% \mathrm{H}_{3} \mathrm{PO}_{4}+\mathrm{MgSO}_{4}$; (d) $85 \% \mathrm{H}_{3} \mathrm{PO}_{4}+\mathrm{MgCl}_{2} \cdot 6 \mathrm{H}_{2} \mathrm{O}$.
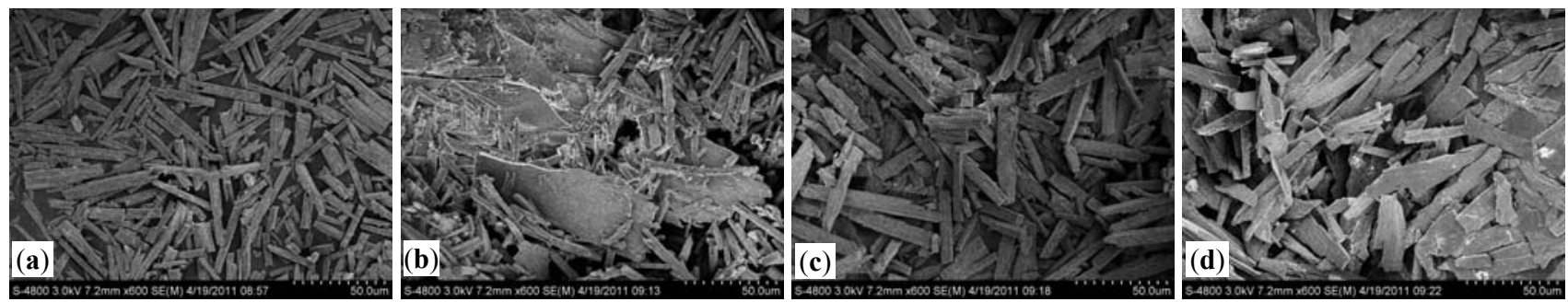

The COD reduction was lower when compared with the corresponding $\mathrm{NH}_{4}{ }^{+}-\mathrm{N}$ removal fractions in the experiment (Figure 1), which implies that the struvite precipitation technique is highly selective for $\mathrm{NH}_{4}{ }^{+}-\mathrm{N}$. This result is in good agreement with those reported by $\mathrm{Li}$ [11] and indicates that a subsequent biological treatment process may be needed to remove the residual COD.

The change in the $\mathrm{pH}$ of the solutions during the experiments was similar regardless of the choice of chemicals used. A decrease in $\mathrm{pH}$ value was observed in the course of the struvite reactions (Figure 1). Stratful [19] demonstrated that, in terms of thermodynamic equilibrium, hydrogen was released into the solution when struvite was formed, resulting in a decrease in $\mathrm{pH}$.

\subsection{Effect of $p H$}

$\mathrm{pH}$ is an important factor for struvite precipitation because it has a direct influence on the solubility of struvite and its thermodynamic properties [7]. The optimum $\mathrm{pH}$ for struvite precipitation has been widely investigated. In previous literature concerning struvite precipitation, optimum $\mathrm{pH}$ values of 8.5 [20,21], 9 [22], 8.9-9.25 [8], and 9.5-10.5 [23] were reported. In this study, to determine the 
optimum $\mathrm{pH}$ for $\mathrm{NH}_{4}{ }^{+} \mathrm{N}$ removal in 7-ACA wastewater, the experiments were performed at a $\mathrm{pH}$ range of 7 to 11. Based on previous results, $\mathrm{MgCl}_{2} \cdot 6 \mathrm{H}_{2} \mathrm{O}$ and $85 \% \mathrm{H}_{3} \mathrm{PO}_{4}$ were used in subsequent batch experiments. The molar ratio of $\mathrm{Mg}^{2+}: \mathrm{NH}_{4}{ }^{+}-\mathrm{N}: \mathrm{PO}_{4}{ }^{3-}-\mathrm{P}$ was at a stoichiometric ratio of $1: 1: 1$. Figure 4 showed the obtained results.

Figure 4. Effect of $\mathrm{pH}$ on $\mathrm{NH}_{4}{ }^{+}-\mathrm{N}$ and $\mathrm{COD}$ removals, residual $\mathrm{PO}_{4}{ }^{3-}-\mathrm{P}$ at $\mathrm{Mg}^{2+}: \mathrm{NH}_{4}{ }^{+}-\mathrm{N}$ : $\mathrm{PO}_{4}{ }^{3-}-\mathrm{P}$ molar ratio of $1: 1: 1$ and mixing time $15 \mathrm{~min}$.

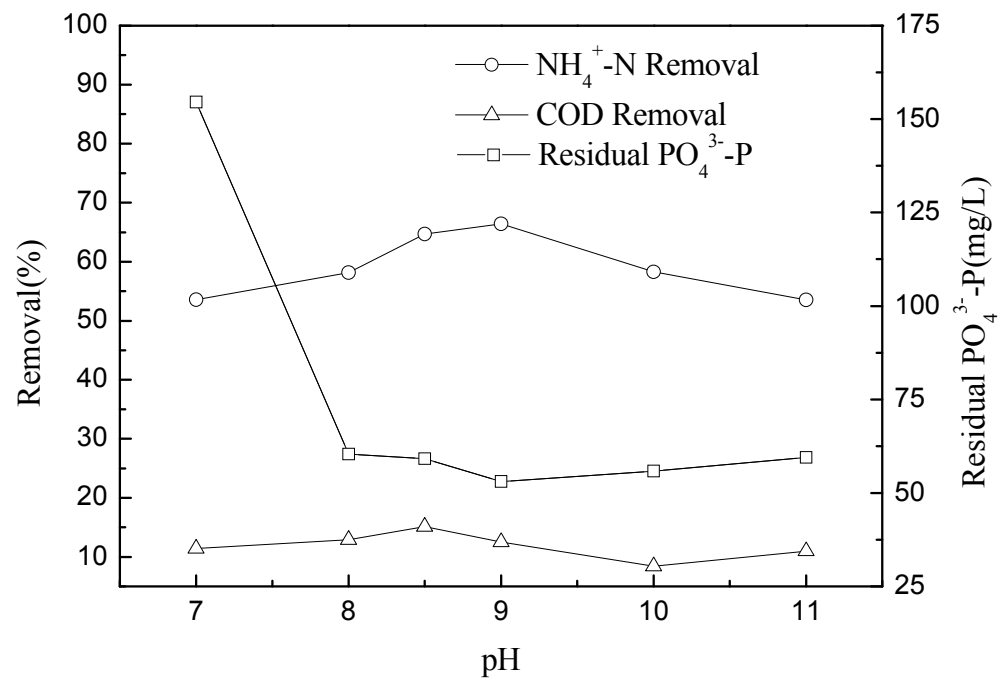

Under otherwise constant precipitation conditions, changes in $\mathrm{pH}$ lead to a direct change in the degree of supersaturation during the precipitation process. At $\mathrm{pH} \mathrm{7,} \mathrm{no} \mathrm{struvite} \mathrm{was} \mathrm{produced} \mathrm{at}$ detectable levels, while at $\mathrm{pH} 8$, only a minute amount of very small crystals were produced. The growth of struvite crystals improved above $\mathrm{pH} 8$, and the amount of precipitate at the bottom of beaker increased when the $\mathrm{pH}$ of the solution was gradually raised to 9 . The struvite product was formed rapidly and settled quickly at the bottom of the beaker after stirring ceased at $\mathrm{pH} 9$. However, the amount and the speed of formation of struvite precipitate decreased substantially at $\mathrm{pH}$ values of 10 and 11. Therefore, the best experimental ammonia removal was obtained at $\mathrm{pH}$ 9. At higher $\mathrm{pH}$, the ammonia volatilization is serious. Air flow also plays an important role in ammonia-nitrogen volatilization. However, on the basis of the present experimental procedure (without stripping and only 15 min of stirring time) and also other findings in the literature [16,18], it can be concluded that ammonia volatilization is negligible on the removal of $\mathrm{NH}_{4}{ }^{+} \mathrm{N}$ from the 7-ACA wastewater, as compared to struvite precipitation. It was likely that when the $\mathrm{pH}$ was excessively high, $\mathrm{Mg}_{3}\left(\mathrm{PO}_{4}\right)_{2}$ was formed instead of struvite, which led to a decrease in the $\mathrm{NH}_{4}{ }^{+}-\mathrm{N}$ removal efficiency. $\mathrm{H}^{+}$in the reaction solution should inhibit struvite precipitation when the $\mathrm{pH}$ is lower than the optimum point, which agrees with the reduced precipitation observed at lower $\mathrm{pH}$. The optimum $\mathrm{pH}$ for the removal of ammonia observed in this experiment was consistent with other studies. Booker [24] reported that $\mathrm{pH}$ 9.2 was optimum, whereas Tünay [25] found $\mathrm{pH} 8.5-9.3$ to be the optimal range. The morphology of struvite precipitation was observed both above and below the optimum $\mathrm{pH}$ of 9 (Figure 5). 
Figure 5. Morphology of struvite precipitation at different $\mathrm{pH}$ : (a) $\mathrm{pH}=8$ (b) $\mathrm{pH}=9$ (c) $\mathrm{pH}=10$.
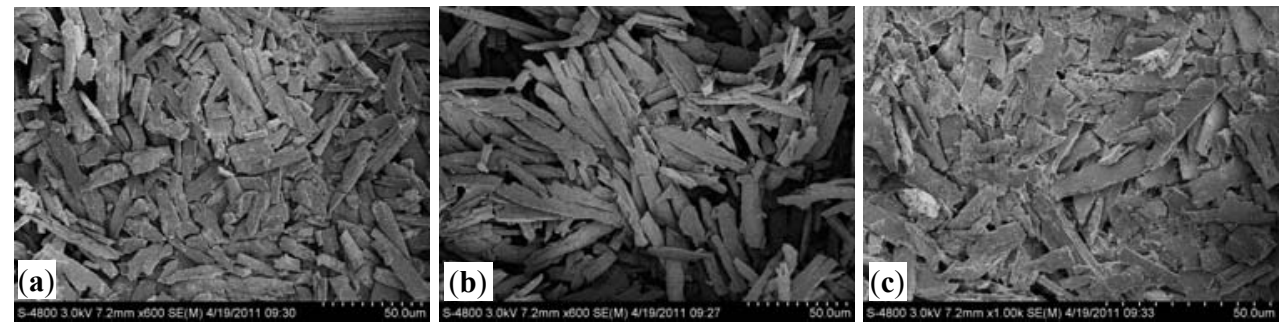

Figure 4 also displayed the $\mathrm{COD}$ reduction and residual $\mathrm{PO}_{4}{ }^{3-}-\mathrm{P}$ for the 7-ACA wastewater. With an increase in $\mathrm{pH}$, the percentage of COD removal maintained previous trends within a narrow range of $16-18 \%$. The residual $\mathrm{PO}_{4}{ }^{3-}-\mathrm{P}$ in the 7 -ACA wastewater was higher at $\mathrm{pH}<8$ than that at $\mathrm{pH}>8$ conditions. This may be because at low $\mathrm{pH}$, further crystallization and precipitation of struvite was inhibited, and the residual concentration of $\mathrm{PO}_{4}{ }^{3-}-\mathrm{P}$ was maintained. The results indicate that the optimum $\mathrm{pH}$ values for the removal of ammonium and phosphate are different. This finding was consistent with the study of Booker [24] who reported that the maximum ammonium removal was found at $\mathrm{pH} 9.2$, whereas the maximum phosphate removal was observed at $\mathrm{pH} 9.8$.

Based on previous results, subsequent experiments were conducted at $\mathrm{pH} 9.0$ with $\mathrm{MgCl}_{2} \cdot 6 \mathrm{H}_{2} \mathrm{O}$ and $85 \% \mathrm{H}_{3} \mathrm{PO}_{4}$ to investigate the effects of different molar ratios on the $\mathrm{NH}_{4}{ }^{+}-\mathrm{N}$ removal efficiency as well as on the residual $\mathrm{PO}_{4}{ }^{3-}-\mathrm{P}$ and COD.

\subsection{Effect of the $\mathrm{Mg}^{2+}: \mathrm{NH}_{4}{ }^{+}-\mathrm{N}: \mathrm{PO}_{4}{ }^{3-}-\mathrm{P}$ Molar Ratio}

Effects of different $\mathrm{Mg}^{2+}: \mathrm{NH}_{4}{ }^{+}-\mathrm{N}: \mathrm{PO}_{4}{ }^{3-}-\mathrm{P}$ molar ratios on $\mathrm{NH}_{4}{ }^{+}-\mathrm{N}$ removal, as well as on COD reduction and the residual $\mathrm{PO}_{4}{ }^{3-}-\mathrm{P}$ in the wastewater, were investigated for various molar concentrations. No significant improvement was observed in $\mathrm{NH}_{4}{ }^{+}-\mathrm{N}$ removal with increasing molar ratios of $\mathrm{Mg}^{2+}: \mathrm{NH}_{4}{ }^{+}-\mathrm{N}$ when the $\mathrm{NH}_{4}{ }^{+}-\mathrm{N}: \mathrm{PO}_{4}{ }^{3-}-\mathrm{P}$ ratio was fixed at 1:1 (Figure 6a). This may be due to the formation of other precipitates at higher molar ratios. For example, when an excess concentration of $\mathrm{Mg}^{2+}$ is in highly alkaline conditions, solid phase $\mathrm{Mg}(\mathrm{OH})_{2}$ may precipitate. The precipitation of $\mathrm{Mg}_{3}\left(\mathrm{PO}_{4}\right)_{2}$ may also occur because the precipitation potential of this compound is enhanced by the addition of additional $\mathrm{Mg}$ substrate. These results agree with the findings of several previous studies [25,26]. However, some scientists [3,27] have shown that $\mathrm{NH}_{4}{ }^{+}-\mathrm{N}$ removal was generally affected by the amount of magnesium available to the struvite precipitation reaction. In particular, Stratful [19] reported that magnesium ions were a limiting factor for struvite precipitation. The difference between these two contrary results may be due to the properties of the applied water.

The removal fraction of COD increased with an increasing concentration of $\mathrm{Mg}^{2+}$ species. COD removal reached $20.1 \%$ at the $\mathrm{Mg}^{2+}: \mathrm{NH}_{4}{ }^{+}-\mathrm{N}$ molar ratio of $1.3: 1$. Magnesium ions are widely used as flocculants to remove particulate organic matter in 7-ACA wastewater. The concentration of residual $\mathrm{PO}_{4}{ }^{3-}$-P first decreased and then increased with increasing $\mathrm{Mg}^{2+}: \mathrm{NH}_{4}{ }^{+}-\mathrm{N}$ ratio, indicating the existence of an optimum $\mathrm{Mg}^{2+}: \mathrm{NH}_{4}{ }^{+}-\mathrm{N}$ ratio for the removal of $\mathrm{PO}_{4}{ }^{3-}-\mathrm{P}$.

The effect of the $\mathrm{PO}_{4}{ }^{3-}-\mathrm{P}: \mathrm{NH}_{4}{ }^{+}-\mathrm{N}$ molar ratio was determined at a fixed $\mathrm{Mg}^{2+}: \mathrm{NH}_{4}{ }^{+}-\mathrm{N}$ ratio of $1: 1$ (Figure 6b). Theoretically, $100 \%$ of $\mathrm{NH}_{4}{ }^{+}-\mathrm{N}$ should be removed when the molar ratio of $\mathrm{Mg}^{2+}: \mathrm{NH}_{4}{ }^{+}-\mathrm{N}$ : $\mathrm{PO}_{4}{ }^{3-}-\mathrm{P}$ in the solution is equal to the stoichiometric value. However, the removal efficiency of $\mathrm{NH}_{4}{ }^{+}-\mathrm{N}$ 
was $81.3 \%$ when the $\mathrm{PO}_{4}{ }^{3-}-\mathrm{P}: \mathrm{NH}_{4}{ }^{+}-\mathrm{N}$ ratio was $1: 1$. The removal efficiency of $\mathrm{NH}_{4}{ }^{+}-\mathrm{N}$ was increased a little with a rise of about $2.6 \%$ at the $\mathrm{PO}_{4}{ }^{3-}-\mathrm{P}: \mathrm{NH}_{4}{ }^{+}-\mathrm{N}$ ratio of $1.1: 1$ and then decreased with the $\mathrm{PO}_{4}{ }^{3-}-\mathrm{P}: \mathrm{NH}_{4}{ }^{+}-\mathrm{N}$ ratio above $1.1: 1$, but the removal efficiency remained lower than the theorical value. Based on the wastewater characteristics and selected operating conditions, it may be possible to enhance the recovery of $\mathrm{NH}_{4}{ }^{+}-\mathrm{N}$ by adding excess concentrations of $\mathrm{PO}_{4}^{3-}-\mathrm{P}$. However, this application may be limited in practice due to excessively high levels of residual $\mathrm{PO}_{4}{ }^{3-}-\mathrm{P}$ after precipitation. As observed in Figure 6b, the concentration of residual $\mathrm{PO}_{4}{ }^{3-}-\mathrm{P}$ in the wastewater was substantially increased when the $\mathrm{PO}_{4}{ }^{3-}-\mathrm{P}: \mathrm{NH}_{4}{ }^{+}-\mathrm{N}$ ratio was above $1.1: 1$. It is important to note that residual orthophosphate is itself a potential pollutant in the aquatic environment.

Figure 6. Effect of the mole ratio of $\mathrm{Mg}^{2+}: \mathrm{NH}_{4}{ }^{+}-\mathrm{N}: \mathrm{PO}_{4}{ }^{3-}-\mathrm{P}$ on the removal of $\mathrm{NH}_{4}{ }^{+}-\mathrm{N}$ and the residual phosphate at $\mathrm{pH} 9.0$ and mixing time $15 \mathrm{~min}$, the molar ratio range of (a) $\mathrm{Mg}^{2+}: \mathrm{NH}_{4}{ }^{+}-\mathrm{N}: \mathrm{PO}_{4}{ }^{3-}-\mathrm{P}=(0.8-1.3): 1: 1 ;$ (b) $\mathrm{Mg}^{2+}: \mathrm{NH}_{4}{ }^{+}-\mathrm{N}: \mathrm{PO}_{4}{ }^{3-}-\mathrm{P}=1: 1:(0.8-1.3)$.

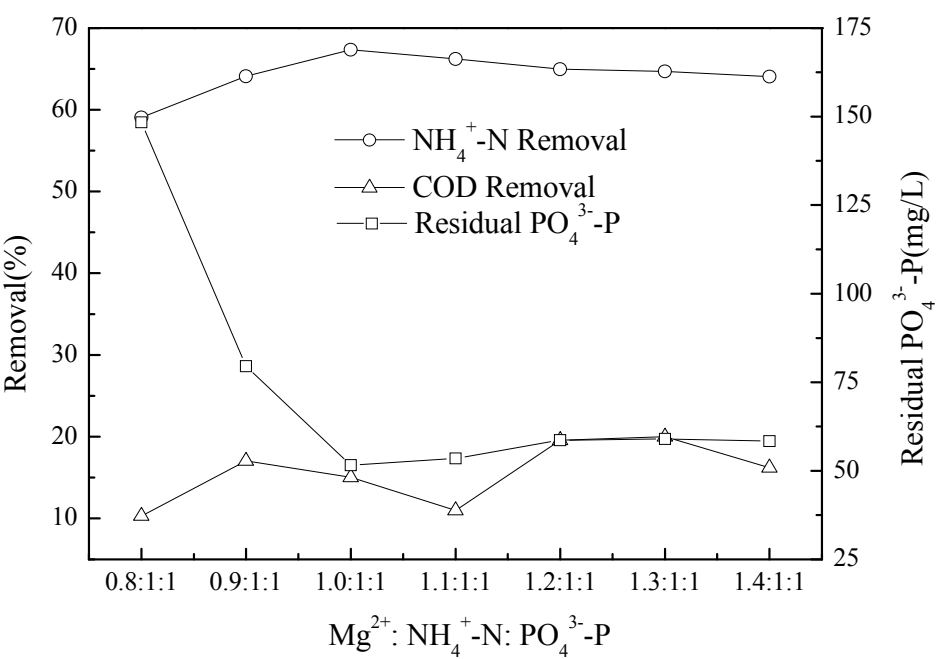

(a)

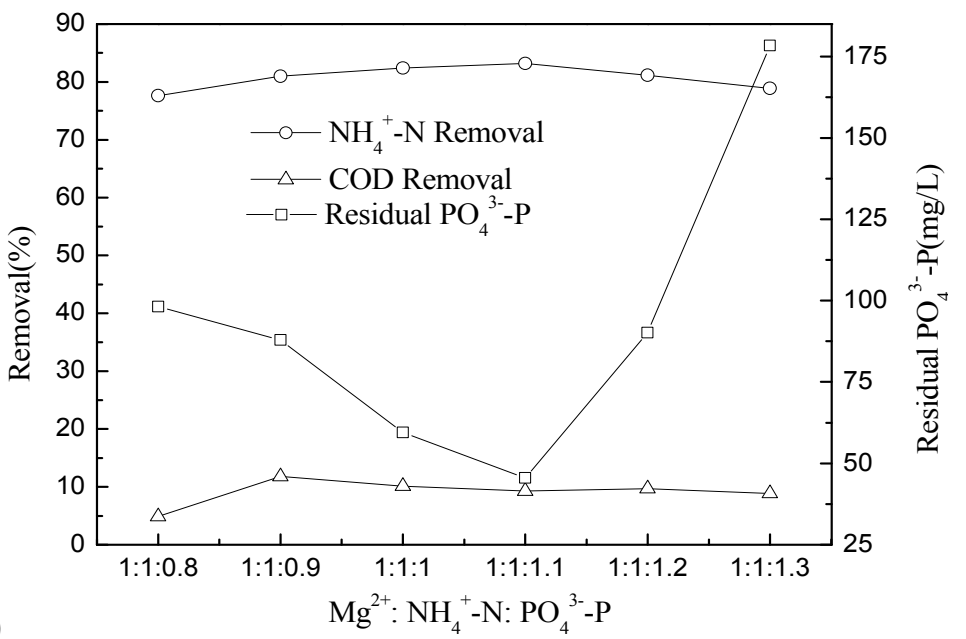

The experimental results showed that $\mathrm{NH}_{4}{ }^{+}-\mathrm{N}$ removal reached nearly the maximum value at the stochiometric ratio. These results agreed with the findings of the previous study [27]. The residual $\mathrm{PO}_{4}{ }^{3-}-\mathrm{P}$ was higher when the $\mathrm{Mg}^{2+}: \mathrm{NH}_{4}{ }^{+}-\mathrm{N}: \mathrm{PO}_{4}{ }^{3-}-\mathrm{P}$ at stochiometric ratio than the $\mathrm{Mg}^{2+}: \mathrm{NH}_{4}{ }^{+}-\mathrm{N}$ : $\mathrm{PO}_{4}{ }^{3-}-\mathrm{P}$ of $1: 1: 1.1$. Taking into account the need to avoid excess residual $\mathrm{PO}_{4}{ }^{3-}-\mathrm{P}$ in the 7-ACA wastewater, the $\mathrm{Mg}^{2+}: \mathrm{NH}_{4}{ }^{+}-\mathrm{N}: \mathrm{PO}_{4}{ }^{3-}-\mathrm{P}$ molar ratio of $1: 1: 1.1$ was determined to be sufficient for the removal of $\mathrm{NH}_{4}{ }^{+}-\mathrm{N}$ from 7-ACA wastewater by struvite precipitation. 


\subsection{Effect of Mixing Time}

Figure 7 describes the effect of mixing time on the removal of $\mathrm{NH}_{4}{ }^{+}-\mathrm{N}$. The $\mathrm{Mg}^{2+}: \mathrm{NH}_{4}{ }^{+}-\mathrm{N}: \mathrm{PO}_{4}{ }^{3-}-\mathrm{P}$ molar ratio was fixed at a ratio of 1:1:1.1, and the initial $\mathrm{pH}$ was 9.0. Overall removal of $\mathrm{NH}_{4}{ }^{+}-\mathrm{N}$ was observed to be similar at different mixing times. At short mixing times, the removal efficiency of $\mathrm{NH}_{4}{ }^{+}-\mathrm{N}$ was not significantly reduced. As the mixing time increased, the removal efficiencies of $\mathrm{NH}_{4}{ }^{+}-\mathrm{N}$ did not significantly increase. The mixing time between 5 and $60 \mathrm{~min}$ had a negligible effect on the production of struvite, suggesting that struvite crystals form homogeneously under these conditions and that precipitation is rapid. Examination of the precipitate by SEM microscopy revealed that the maximum crystal size increased with time (Figure 8). Crystals up to $20 \mu \mathrm{m}$ were precipitated at $10 \mathrm{~min}$. At a mixing time of $60 \mathrm{~min}$, the maximum crystal size had increased, with some crystals reaching lengths of $75 \mu \mathrm{m}$. Stratful [19] also investigated the effect of reaction time on the precipitation of struvite and obtained the same conclusion. Some of the crystals were broken with the time increasing, because of the low strength of the crystal, which were shown in Figure 8. We also found that the precipitation system was impeded. The residual phosphate was lowest at mixing time 20 min (Figure 7). A little amount of phosphate may be released from the broking struvite when the mixing time more than 20 min. Kim [9] investigated the effect of mixing intensity and mixing duration on struvite precipitation and reported that mixing enhanced the transfer of mass from the solute to the crystals, resulting in improved struvite crystallization and growth.

Figure 7. Effect of the mixing time on the removal of $\mathrm{NH}_{4}{ }^{+}-\mathrm{N}$ and the residual phosphate in the 7-ACA wastewater at $\mathrm{pH} 9$ and the molar ratio of $\mathrm{Mg}^{2+}: \mathrm{NH}_{4}{ }^{+}-\mathrm{N}: \mathrm{PO}_{4}{ }^{3-}-\mathrm{P}$ of $1: 1: 1.1$.

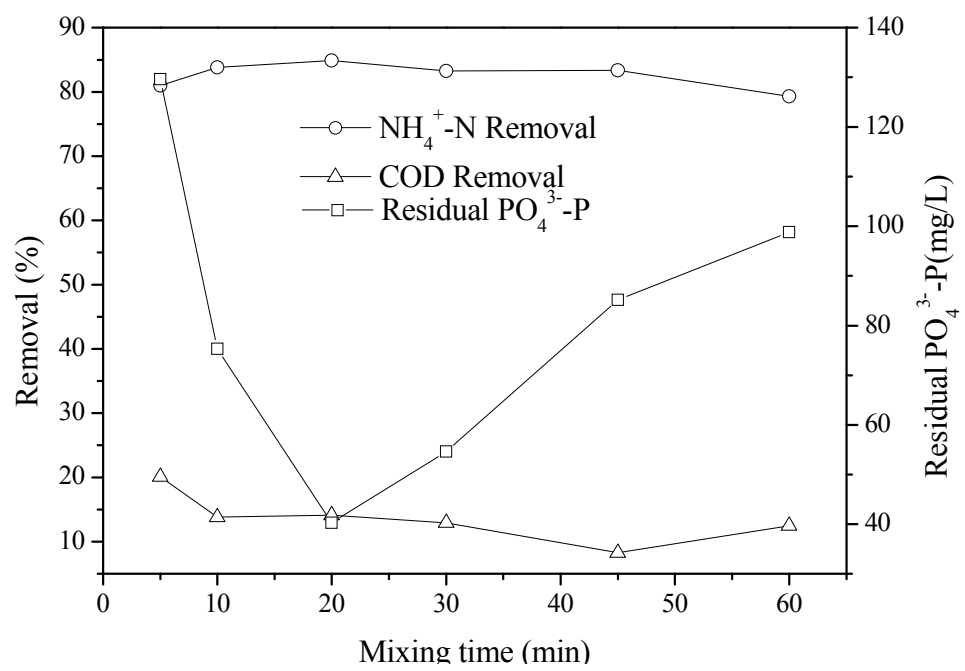

Figure 8. Morphology of struvite precipitation at various mixing times: (a) mixing time $=$ $10 \mathrm{~min}$; (b) mixing time $=20 \mathrm{~min}$; (c) mixing time $=45 \mathrm{~min}$.
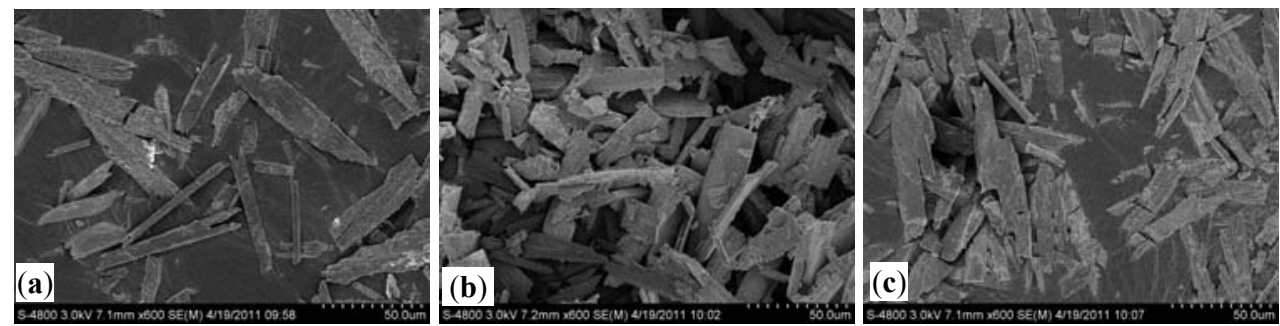


\section{Experimental}

\subsection{7-ACA Wastewater}

The 7-ACA wastewater used in this study was taken from an enzymatic transformation-based production line for antibiotics at a pharmaceutical plant in Hebei, China. The wastewater was generated from the oxidative deamination and hydrolysis catalyzed processes of 7-ACA manufacturing. The characteristics of the 7-ACA wastewater are summarized in Table 2 . The analysis techniques used for the 7-ACA wastewater were in accordance with the Standard Method for the Examination of Water and Wastewater [28].

Table 2. Characteristics of 7-ACA wastewater.

\begin{tabular}{cc}
\hline Parameter & Concentration range \\
\hline Total suspended solid $(\mathrm{mg} / \mathrm{L})$ & $662 \pm 97$ \\
$\mathrm{COD}(\mathrm{mg} / \mathrm{L})$ & $10850 \pm 364$ \\
$\mathrm{pH}$ & $12.2 \pm 0.3$ \\
$\mathrm{NH}_{4}{ }^{+}-\mathrm{N}(\mathrm{mg} / \mathrm{L})$ & $1120 \pm 82$ \\
$\mathrm{PO}_{4}{ }^{3-}-\mathrm{P}(\mathrm{mg} / \mathrm{L})$ & $36 \pm 2$ \\
Turbidity $(\mathrm{NTU})$ & $71 \pm 19$ \\
Biological oxygen demand $(\mathrm{mg} / \mathrm{L})$ & Under limitation \\
\hline
\end{tabular}

\subsection{Reagents}

For struvite formation, three different $\mathrm{Mg}^{2+}$ providing chemicals, namely $\mathrm{MgO}, \mathrm{MgCl}_{2} \cdot 6 \mathrm{H}_{2} \mathrm{O}$ and $\mathrm{MgSO}_{4}$, were compared in the experiments. $\mathrm{H}_{3} \mathrm{PO}_{4}(85 \%), \mathrm{Na}_{3} \mathrm{PO}_{4} \cdot 12 \mathrm{H}_{2} \mathrm{O}$ and $\mathrm{NaH}_{2} \mathrm{PO}_{4} \cdot 2 \mathrm{H}_{2} \mathrm{O}$ were used as alternate sources of orthophosphate ions, and $8 \mathrm{M} \mathrm{NaOH}$ and $1 \mathrm{M} \mathrm{NaOH}$ were used to control $\mathrm{pH}$ in the solutions. All chemicals used were of analytical grade.

\subsection{Experimental Procedures}

The experiments were performed at $298.15 \mathrm{~K}$ with a ZRS-6 variable-speed jar test apparatus (Tangshan Dachang Chemical Ltd., Tangshan, China). The jars were made of polytetrafluoroethene with dimensions of $\Phi 9.5 \mathrm{~cm} \times 15 \mathrm{~cm}$ and held $1.0 \mathrm{~L}$ liquid. A two-blade propeller (polytetrafluoroethylene) with diameter of $2.5 \mathrm{~cm}$ and height of $7.6 \mathrm{~cm}$ was used for stirring.

Nine combinations of chemicals, including $85 \% \mathrm{H}_{3} \mathrm{PO}_{4}+\mathrm{MgO}$ (A1), $\mathrm{Na}_{3} \mathrm{PO}_{4} \cdot 12 \mathrm{H}_{2} \mathrm{O}+\mathrm{MgO}$ (A2), $\mathrm{NaH}_{2} \mathrm{PO}_{4} \cdot 2 \mathrm{H}_{2} \mathrm{O}+\mathrm{MgO}(\mathrm{A} 3), 85 \% \mathrm{H}_{3} \mathrm{PO}_{4}+\mathrm{MgCl}_{2} \cdot 6 \mathrm{H}_{2} \mathrm{O}$ (A4), $\mathrm{NaH}_{2} \mathrm{PO}_{4} \cdot 2 \mathrm{H}_{2} \mathrm{O}+\mathrm{MgCl}_{2} \cdot 6 \mathrm{H}_{2} \mathrm{O}$ (A5), $\mathrm{Na}_{3} \mathrm{PO}_{4} \cdot 12 \mathrm{H}_{2} \mathrm{O}+\mathrm{MgCl}_{2} \cdot 6 \mathrm{H}_{2} \mathrm{O}(\mathrm{A} 6), 85 \% \mathrm{H}_{3} \mathrm{PO}_{4}+\mathrm{MgSO}_{4}(\mathrm{~A} 7), \mathrm{Na}_{3} \mathrm{PO}_{4} \cdot 12 \mathrm{H}_{2} \mathrm{O}+\mathrm{MgSO}_{4}$ (A8) and $\mathrm{NaH}_{2} \mathrm{PO}_{4} \cdot 2 \mathrm{H}_{2} \mathrm{O}+\mathrm{MgSO}_{4}$ (A9) were employed to select the best combination in terms of $\mathrm{NH}_{4}{ }^{+}-\mathrm{N}$ removal from 7-ACA wastewater.

Three factors that affect ammonium removal were studied: $\mathrm{pH}$, the molar ratio of $\mathrm{Mg}^{2+}: \mathrm{NH}_{4}{ }^{+}-\mathrm{N}$ : $\mathrm{PO}_{4}{ }^{3-}-\mathrm{P}$, and the mixing time. The detailed precipitation parameters are listed in Table 3 . All batch experiments were performed in duplicate. 
Table 3. Experimental conditions of struvite precipitation for the removal of $\mathrm{NH}_{4}{ }^{+}-\mathrm{N}$ (initial $\mathrm{NH}_{4}{ }^{+}-\mathrm{N}$ concentration of $1,128 \mathrm{mg} / \mathrm{L}$ ).

\begin{tabular}{|c|c|c|c|c|}
\hline Entry & $\mathbf{p H}$ & $\begin{array}{c}\text { Molar ratio of } \mathrm{Mg}^{2+}: \mathrm{NH}_{4}{ }^{+}-\mathrm{N}: \\
\mathrm{PO}_{4}{ }^{3-}-\mathrm{P}\end{array}$ & $\begin{array}{c}\text { Amount of 85\% } \mathrm{H}_{3} \mathrm{PO}_{4}+ \\
\mathrm{MgCl}_{2} \cdot 6 \mathrm{H}_{2} \mathrm{O}(\mathrm{g}+\mathrm{g}) \\
\end{array}$ & $\begin{array}{l}\text { Mixing time } \\
(\text { min })\end{array}$ \\
\hline 1 & 7 & $1: 1: 1$ & $12.5+6.1$ & 15 \\
\hline 2 & 8 & $1: 1: 1$ & $12.5+6.1$ & 15 \\
\hline 3 & 8.5 & $1: 1: 1$ & $12.5+6.1$ & 15 \\
\hline 4 & 9 & $1: 1: 1$ & $12.5+6.1$ & 15 \\
\hline 5 & 10 & $1: 1: 1$ & $12.5+6.1$ & 15 \\
\hline 6 & 11 & $1: 1: 1$ & $12.5+6.1$ & 15 \\
\hline 7 & 9 & $0.8: 1: 1$ & $10+6.1$ & 15 \\
\hline 8 & 9 & $0.9: 1: 1$ & $11.3+6.1$ & 15 \\
\hline 9 & 9 & $1.1: 1: 1$ & $13.8+6.1$ & 15 \\
\hline 10 & 9 & $1.2: 1: 1$ & $15+6.1$ & 15 \\
\hline 11 & 9 & $1.3: 1: 1$ & $16.3+6.1$ & 15 \\
\hline 12 & 9 & $1: 1: 0.8$ & $12.5+4.9$ & 15 \\
\hline 13 & 9 & 1:1:0.9 & $12.5+5.5$ & 15 \\
\hline 14 & 9 & $1: 1: 1.1$ & $12.5+6.7$ & 15 \\
\hline 15 & 9 & $1: 1: 1.2$ & $12.5+7.3$ & 15 \\
\hline 16 & 9 & $1: 1: 1.3$ & $12.5+7.9$ & 15 \\
\hline 17 & 9 & 1:1:1.1 & $12.5+6.7$ & 5 \\
\hline 18 & 9 & $1: 1: 1.1$ & $12.5+6.7$ & 10 \\
\hline 19 & 9 & 1:1:1.1 & $12.5+6.7$ & 20 \\
\hline 20 & 9 & 1:1:1.1 & $12.5+6.7$ & 30 \\
\hline 21 & 9 & 1:1:1.1 & $12.5+6.7$ & 60 \\
\hline
\end{tabular}

The effectiveness of $\mathrm{pH}$ was investigated first. The test jar was filled with ammonia/phosphate solutions, and the $\mathrm{pH}$ was adjusted to the given values (from 7 to 11 ) in different jars using $1 \mathrm{~mol} \cdot \mathrm{L}^{-1}$ $\mathrm{NaOH}$. The solutions were then stirred at $100 \mathrm{rpm}$ for $15 \mathrm{~min}$, followed by $30 \mathrm{~min}$ of quiescent settling. When the reaction time had elapsed, the $\mathrm{pH}$ was measured, and the precipitate that had formed was collected by double filtration through a $0.2 \mathrm{~mm}$ membrane filter. After filtration, concentrations of the $\mathrm{NH}_{4}{ }^{+}-\mathrm{N}, \mathrm{PO}_{4}{ }^{3-}-\mathrm{P}$ and COD in solution were analyzed.

The previous procedures were repeated for the other two factors. Based on the preliminary test results, subsequent experiments were then performed at the optimum $\mathrm{pH}$ (as found in the previous step) using the most efficient chemical combination. To maintain the stoichiometric molar ratio (1:1:1) needed for struvite precipitation, $\mathrm{Mg}^{2+}$ and $\mathrm{PO}_{4}{ }^{3-}-\mathrm{P}$ sources was added to ensure high removal efficiencies of $\mathrm{NH}_{4}^{+}-\mathrm{N}$. $\mathrm{A} \mathrm{Mg}^{2+}$ source $\left(\mathrm{MgCl}_{2} \cdot 6 \mathrm{H}_{2} \mathrm{O}\right)$ and a phosphate source $\left(85 \% \mathrm{H}_{3} \mathrm{PO}_{4}\right)$ in solid phase were added to the beaker to adjust the molar ratio of $\mathrm{Mg}^{2+}: \mathrm{NH}_{4}{ }^{+}-\mathrm{N}: \mathrm{PO}_{4}{ }^{3-}-\mathrm{P}$. To test the effects of reaction time on the removal of $\mathrm{NH}_{4}{ }^{+}-\mathrm{N}$, on $\mathrm{COD}$ and the residual $\mathrm{PO}_{4}{ }^{3-}-\mathrm{P}$ in wastewater, mixing times between 5-60 min were chosen. 


\subsection{Analytical Methods}

COD, total suspended solids, $\mathrm{NH}_{4}{ }^{3+}-\mathrm{N}, \mathrm{PO}_{4}{ }^{3-}-\mathrm{P}$, turbidity and $\mathrm{pH}$ analyses were performed at the Water Quality Lab, as described in the Standard Method for the Examination of Water and Wastewater [29]. Crystal phases of the struvites were obtained by XRD (D/max 2500PC, Rigaku, Tokyo, Japan) with $\mathrm{Cu} \mathrm{K} \alpha$ radiation of wavelength $0.154 \mathrm{~nm}$ in the range of $2 \theta=10-80^{\circ}$ with a scan speed of $1.2 \% \mathrm{~min}$. The morphologies of the struvites were analyzed by SEM (S-4800I, Hitachi, Tokyo, Japan) at $3.0 \mathrm{keV}$, which was equipped with an energy dispersive analysis system of X-ray (EDS).

\subsection{Observation and Identification of Crystals}

The struvites were washed with distilled water through the membrane filter and dried at $303.17 \mathrm{~K}$ for $72 \mathrm{~h}$. The crystal size was examined using an Olympus BH-2 light microscope with a camera attachment. X-ray diffraction using a Siemens D5000 diffractometer and monochrome CoKa radiation $(40 \mathrm{kV}, 30 \mathrm{~mA})$ was used to determine the identity of the precipitate. Scans from 2 to $75^{\circ} 2 \theta$ were recorded with a scan speed of $0.08^{\circ} 2 \theta$ per min. The scan length was $0.02^{\circ}$, and the time constant was $15 \mathrm{~s}$ by reference to Card Socabin from Diffract AT.

\section{Conclusions}

Struvite precipitation was applied for the removal of $\mathrm{NH}_{4}{ }^{+} \mathrm{N}$ from 7-ACA wastewater. Nine combinations of chemicals were used $\left[85 \% \mathrm{H}_{3} \mathrm{PO}_{4}+\mathrm{MgO}\right.$ (A1), $\mathrm{Na}_{3} \mathrm{PO}_{4} \cdot 12 \mathrm{H}_{2} \mathrm{O}+\mathrm{MgO}$ (A2), $\mathrm{NaH}_{2} \mathrm{PO}_{4} \cdot 2 \mathrm{H}_{2} \mathrm{O}+\mathrm{MgO}(\mathrm{A} 3), 85 \% \mathrm{H}_{3} \mathrm{PO}_{4}+\mathrm{MgCl}_{2} \cdot 6 \mathrm{H}_{2} \mathrm{O}$ (A4), $\mathrm{NaH}_{2} \mathrm{PO}_{4} \cdot 2 \mathrm{H}_{2} \mathrm{O}+\mathrm{MgCl}_{2} \cdot 6 \mathrm{H}_{2} \mathrm{O}$ (A5), $\mathrm{Na}_{3} \mathrm{PO}_{4} \cdot 12 \mathrm{H}_{2} \mathrm{O}+\mathrm{MgCl}_{2} \cdot 6 \mathrm{H}_{2} \mathrm{O}(\mathrm{A} 6), 85 \% \mathrm{H}_{3} \mathrm{PO}_{4}+\mathrm{MgSO}_{4}(\mathrm{~A} 7), \mathrm{Na}_{3} \mathrm{PO}_{4} \cdot 12 \mathrm{H}_{2} \mathrm{O}+\mathrm{MgSO}_{4}$ (A8) and $\left.\mathrm{NaH}_{2} \mathrm{PO}_{4} \cdot 2 \mathrm{H}_{2} \mathrm{O}+\mathrm{MgSO}_{4}(\mathrm{~A} 9)\right]$ to determine the most efficient combination for $\mathrm{NH}_{4}^{+}-\mathrm{N}$ removal. The effects of the operational parameters on struvite precipitation were also investigated. Based on the results of the experimental tests, the following conclusions could be drawn:

(1) $\mathrm{MgCl}_{2} \cdot 6 \mathrm{H}_{2} \mathrm{O}+85 \% \mathrm{H}_{3} \mathrm{PO}_{4}$ was the most efficient combination for $\mathrm{NH}_{4}^{+}-\mathrm{N}$ removal compared with the other chemical combinations studied. Furthermore, the lowest concentration of the residual $\mathrm{PO}_{4}{ }^{3-}-\mathrm{P}$ was obtained with the same combination.

(2) $\mathrm{pH}$ was an important parameter in the removal of $\mathrm{NH}_{4}{ }^{+}-\mathrm{N}$ from 7-ACA wastewater. The optimum $\mathrm{pH}$ for $\mathrm{NH}_{4}{ }^{+}-\mathrm{N}$ removal was clearly observed at $\mathrm{pH} 9$, and a slightly higher $\mathrm{pH}$ would be required for efficient residual $\mathrm{PO}_{4}{ }^{3-}-\mathrm{P}$ removal.

(3) Excess quantities of $\mathrm{Mg}^{2+}$ and $\mathrm{PO}_{4}{ }^{3-}-\mathrm{P}$ were of little benefit to struvite formation. A $\mathrm{Mg}^{2+}: \mathrm{NH}_{4}{ }^{+}-\mathrm{N}: \mathrm{PO}_{4}{ }^{3-}-\mathrm{P}$ molar ratio of $1: 1: 1.1$ was sufficient for $\mathrm{NH}_{4}{ }^{+}-\mathrm{N}$ removal with the appropriate levels of residual $\mathrm{PO}_{4}{ }^{3-}-\mathrm{P}$ in the 7 -ACA.

\section{Acknowledgments}

This research was supported by the National Technical Major Projects for Water Pollution Prevention and Control in the "11th Five-Year Plan" of China (NO. 2008ZX07529-006) and Natural Science Foundation of China (No. 21106033). 


\section{References and Notes}

1. Liikanen, A.; Martikainen, P.J. Effect of ammonium andoxygen on methane and nitrous oxide fluxes acrosssediment-water interface in a eutrophic lake. Chemosphere 2003, 8, 1287-1293.

2. Lopata, K.R.; Auerswald, L.; Cook, P. Ammonia toxicity and its effect on the growth of the South Africa abalone haliotis midae linnaeus. Aquaculture 2006, 261, 678-687.

3. Lee, S.I.; Weon, S.Y.; Lee, C.W.; Koopman, B. Removal of nitrogen and phosphate from wastewater by addition of bittern. Chemosphere 2003, 51, 265-271.

4. Doyle, J.D.; Parsons, S.A. Struvite formation, control and recovery. Water Res. 2002, 16, 3925-3940.

5. Li, X.Z.; Zhao, Q.L. Recovery of ammonium-nitrogen from landfill leachate as a multi-nutrient fertilizer. Ecol. Eng. 2003, 20, 171-181.

6. Diwani, G.E.; Rafie, S.E.; Ibiari, N.N.E.; El-Aila, H.I. Recovery of ammonia nitrogen from industrial wastewater treatment as struvite slow releasing fertilizer. Desalination 2007, 214, 200-214.

7. Ronteltap, M.; Maurer, M.; Gujer, W. Struvite precipitation thermodynamics in source-separated urine. Water Res. 2007, 5, 977-984.

8. Nelson, N.O.; Mikkelsen, R.L.; Hesterberg, D.L. Struvite precipitation in anaerobic swine lagoon liquid: Effect of $\mathrm{pH}$ and $\mathrm{Mg}: \mathrm{P}$ ratio and determination of rate constant. Bioresource Technol. 2003, 3, 229-236.

9. Kim, D.; Kim, J.; Ryu, H.D.; Lee, S.-I. Effect of mixing on spontaneous struvite precipitation from semiconductor wastewater. Bioresource Technol. 2009, 100, 74-78.

10. Münch, E.V.; Barr, K. Controlled struvite crystallisation for removing phosphorus from anaerobic digester sidestreams. Water Res. 2001, 35, 151-159.

11. Li, X.Z.; Zhao, Q.L. Efficiency of biological treatmentaffected by high strength of ammoniumnitrogen in leachateand chemical precipitation of ammonium-nitrogen as pretreatment. Chemosphere 2001, 44, 37-43.

12. Uludag-Demirer, S.; Demirer, G.N.; Chen, S. Ammonia removal from anaerobically digested dairy manure by struvite precipitation. Process Biochem. 2005, 40, 3667-3674.

13. Ryu, H.D.; Kim, D.; Lee, S.I. Application of struvite precipitation in treating ammonium nitrogen from semiconductor wastewater. J. Hazard. Mater. 2008, 156, 163-169.

14. Marti, N.; Bouzas, A.; Seco, A.; Ferrer, J. Struvite precipitation assessment in anaerobic digestion processes. Chem. Eng. J. 2007, 141, 67-74.

15. Zhang, T.; Ding, L.; Ren, H.; Xiong, X. Ammonium nitrogen removal from coking wastewater by chemical precipitation recycle technology. Water Res. 2009, 43, 5209-5215.

16. Yetilmezsoy, K.; Sapci-Zengin, S. Recovery of ammonium nitrogen from the effluent of UASB treating poultry manure wastewater by MAP precipitation as a slow release fertilizer. J. Hazard. Mater. 2009, 166, 260-269.

17. Altinbas, M.; Ozturk, I.; Aydin, A.F. Ammonia recovery from high strength agro-industry effluents. Water Sci. Technol. 2002, 45, 189-196.

18. Ryu, H.D.; Lee, S. Application of struvite precipitation as a pretreatment in treating swine wastewater. Process Biochem. 2010, 45, 563-572.

19. Stratful, I.; Scrimshaw, M.D.; Lester, N.J. Conditions influencing the precipitation of magnesium ammonium phosphate. Water Res. 2001, 35, 4191-4199. 
20. Suzuki, K.; Tanaka, Y.; Osada, T.; Waki, M. Removal of phosphate, magnesium and calcium from swine wastewater through crystallization enhanced by aeration. Water Res. 2002, 12, 2991-2998.

21. Celen, I.; Buchanan, J.R.; Burns, R.T.; Robinson, R.B.; Raman, D.R. Using chemical equilibrium model to predict amendments required to precipitate phosphorus as struvite in liquid swine manure. Water Res. 2007, 41, 1689-1696.

22. Jaffer, T.A.; Clark, P.P.; Parsons, S.A. Potential phosphorus recovery by struvite formation. Water Res. 2002, 36, 1834-1842.

23. Song, Y.H.; Yuan, P.; Zheng, B.H.; Peng, J.; Yuan, F.; Gao, Y. Nutrients removal and recovery by crystallization of magnesium ammonium phosphate from synthetic swine wastewater. Chemosphere 2007, 69, 319-324.

24. Booker, N.A.; Priestley, A.J.; Fraser, I.H. Struvite formation in wastewater treatment plants: Opportunities for nutrient recovery. Environ. Technol. 1999, 20, 777-782.

25. Tünay, O.; Kabdasli, I.; Orhon, D.; Kolçak, S. Ammonia removal by magnesium ammonium 35 phosphate precipitation in industrial wastewaters. Water Sci. Technol. 1997, 36, 225-228.

26. Li, X.Z.; Zhao, Q.L.; Hao, X.D. Ammonium removal from landfill leachate by chemical precipitation. Waste Manag. 1999, 19, 409-415.

27. Lei, X.; Shimada, S.; Intabon, K.; Maekawa, T. Pretreatment of methane fermentation effluent by physico-chemical processes before applied to soil trenchsystem. Agric. Eng. Int. CIGR Ejournal 2006, 8, 1-15.

28. APHA. Standard Methods for the Examination of Water and Wastewater; American Public Health Association/American Water Works Association/Water Pollution Control Federation: Washington DC, WA, USA, 1998.

Sample Availability: Not available.

(C) 2012 by the authors; licensee MDPI, Basel, Switzerland. This article is an open access article distributed under the terms and conditions of the Creative Commons Attribution license (http://creativecommons.org/licenses/by/3.0/). 